\title{
Small-dispersed dust chemical composition on the leaves of apricot trees (Prúnus armeníaca) in residential area
}

\author{
Irina Glinyanova* \\ Institute of Architecture and Construction, VolgSTU, 400074, Academic 1 st., Volgograd, Russia
}

\begin{abstract}
A study of the small-dispersed dust chemical composition on the leaves of apricot trees (Prúnus armeniaca) in the residential area of the Sredneakhtubinsky district of the Volgograd region was coducted. The aim of the study was to assess the environmental situation in low-rise buildings near functioning constructional and machinery enterprises. The leaves of apricot trees (Prúnus armeniaca), growing in the residential area, were used as passive biomonitors. Chemical analysis of dust particles was carried out with the usage of a scanning electron microscope Versa 3D Dual Beam. As a result of the studies, the chemical composition of small-dispersed dust (PM1, PM2,5, PM10) on the leaves of apricot trees (Prúnus armeníaca), which consisted of $\mathrm{C}, \mathrm{O}, \mathrm{Mg}, \mathrm{Al}, \mathrm{Si}, \mathrm{Cl}, \mathrm{K}, \mathrm{Ca}, \mathrm{F}, \mathrm{P}, \mathrm{S}, \mathrm{Fe}$, Mo. Chemical elements such as: F, P, S, Fe, Mo are not specific for leaf blades of apricot trees (Prúnus armeniaca) and are environmental pollutants that have fallen on the leaves of apricot trees (Prúnus armeníaca) from atmospheric air. In the future, it is necessary to find out the sources of atmospheric air pollution in the residential area by non-specific chemical elements and their compounds for this type of plant in the Sredneahtubinsky district of the Volgograd region, and to develop a set of environmental measures aimed to reduce pollutants emissions into the environment, and improving the quality of life of the population.
\end{abstract}

\section{Introduction}

Many researchers use passive biomonitors to assess air quality. Thus, Zaitseva N.V., May I.V., A.A. Max, S.Yu. Zagorodnov conduct analysis of the dispersion and component composition of the dust to assessment of the exposure to the population in areas of influence of industrial emissions of stationary sources [1]. Kapur S.S., Bamnia B.R.; Kapoor, K. using plants, effectively control air pollution and emphasize its economic efficiency [2]. Norouzi S., Hademi H., Faz Kano A. [etc.] use sycamore plane leaves for biomonitoring of heavy metals [3]. Ram S. S., Majumder S., Chaudhuri P. use plants as adsorbents of dust particles [4].

The term "passive biomonitors" is used mainly for plant organs, which during the season or a long period of time are able to accumulate pollutants from the environment and reveal

\footnotetext{
*Corresponding author: ecoris@yandex.ru
} 
the ecological situation in urban areas. Accordingly, to determine the quality of the environment, many scientists around the world often use plants as biomonitors, for example, leaves of woody plants. On the surface of leaf blades, they study the chemical composition of dust, as well as the chemical composition of plant leaves with dust particles, and predict environmental risks.

For example, Cardoso K.M., De Paula A., Dos Santos J.S. [etc.] use various types of urban trees in the biomonitoring of environmental pollution [5]. Franzaring J., Mbaka G.E., Ambebe T.F. [et al.] show levels of nutrients and metals in the plants in Cameroon mountains as reference values for plant nutrition and environmental monitoring [6]. Tashekova A.Zh., Toropov A.S. consider plant leaves as biogeoindicators of urban environment state [7]. Li P., Sun X., Chen J. [etc.] found absorption of natural radioactive gas Rn-222 and its decay products: $210 \mathrm{~Pb}$ spanish moss Tillandsia usneoides [8].

\section{Results}

In the residential area of the Sredneakhtubinsky district of the Volgograd region, to assess the quality of atmospheric air, were selected a passive biomonitors - apricot tree leaves (Prúnus armeníaca), (Fig.1).

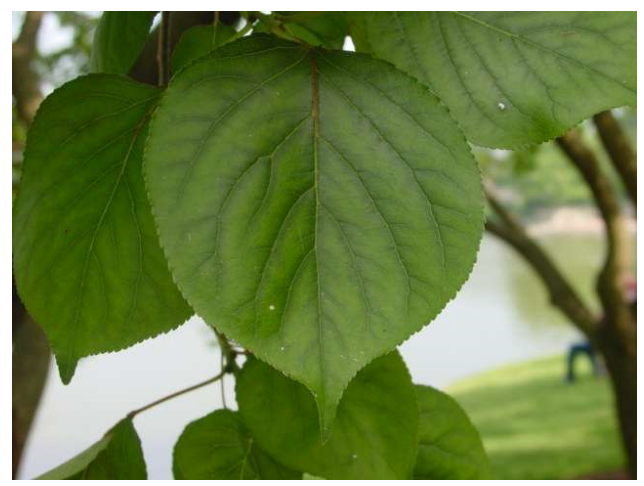

Fig. 1. Apricot leaf (Prúnus armeníaca).

On the leaves of apricot trees (Prúnus armeníaca) dust particles and their chemical composition, as well as the chemical composition of the leaves of apricot trees (Prúnus armeníaca) were studied.

The studies were carried out in low-rise buildings within the borders of the streets: Omskaya, Kavkazskaya, Bolnichnaya, Vorovskogo, etc., which are located in the alleged influence zone of the existing constructional and machinery enterprises.

On the territory of the residential area at different points of distance from the industrial zone were selected leaves of apricot trees (Prúnus armeníaca) in order to study the chemical composition of small-dispersed dust on the leaves of apricot trees (Prúnus armeníaca), the chemical composition of the leaves, and to predict the ecological situation in the residential area of the Sredneahtubinsky district of the Volgograd region.

As an illustration, Fig. 2 (A) shows the surface of an apricot tree leaf (Prúnus armeníaca) with dust particles, including small-dispersed dust: PM1, PM2,5, PM10 (B). 
A)

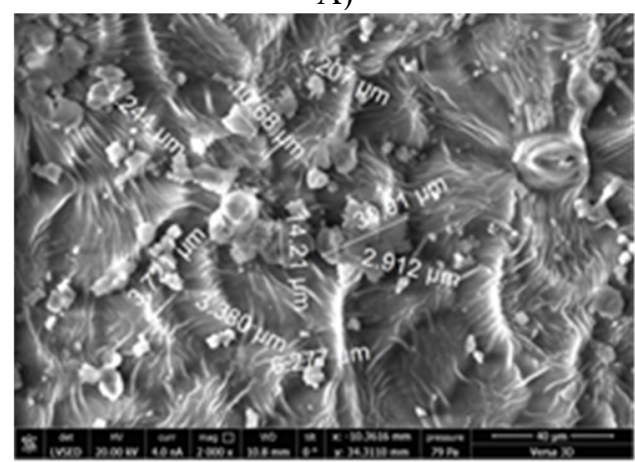

B)

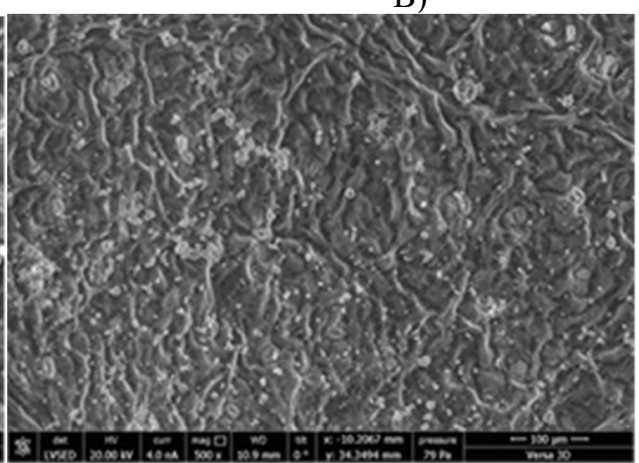

Fig. 2. Photo of the leaves surface of apricot trees (Prúnus armeníaca) with dust particles on the street Omskaya.

Chemical analysis of dust particles was carried out with the usage of a scanning electron microscope Versa 3D Dual Beam.

As a result of the studies, it was found that dust particles on the leaves of apricot trees (Prúnus armeníaca) consist mainly of C, O, Mg, Al, $\mathrm{Si}, \mathrm{Cl}, \mathrm{K}, \mathrm{Ca}, \mathrm{P}$. In some samples leaves of apricot trees (Prúnus armeníaca), for example: on the street Omskaya, registered in small quantities dust particles with F (3,51\%), Mo (0,36\%), Fe (0,25-0,61\%) (Fig.3).

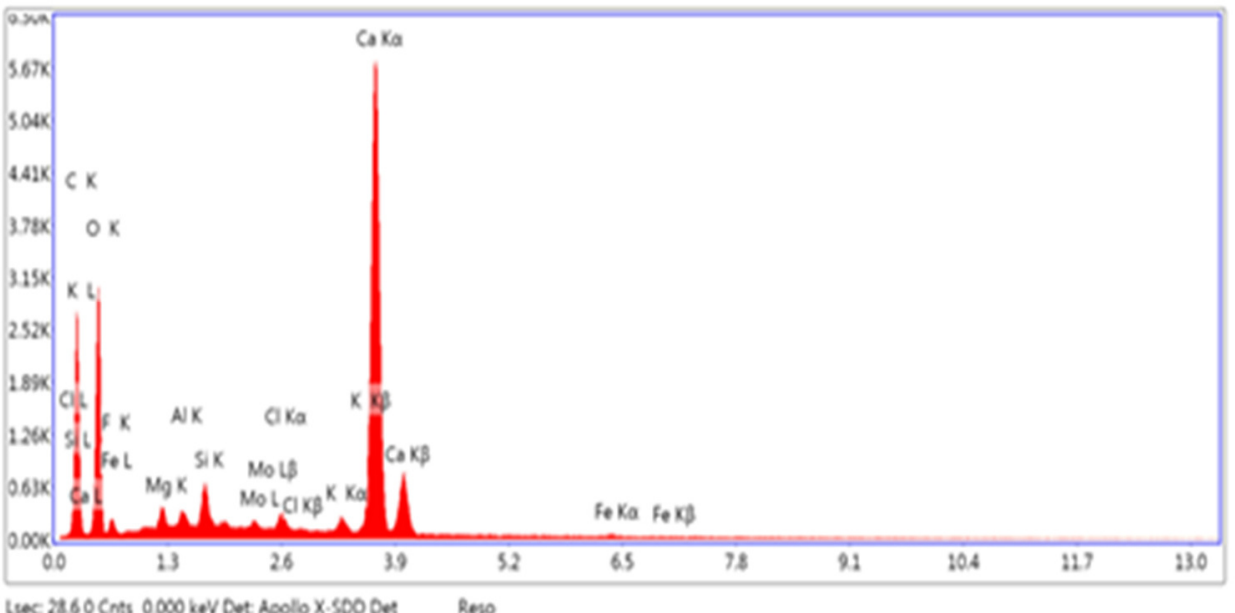

Fig. 3. The chemical composition of the dust particles on the leaves of apricot trees (Prúnus armeníaca) with $\mathrm{Fe}, \mathrm{Mo}, \mathrm{F}$ on the street Omskaya.

Figure 4 shows the chemical composition of the dust particles from the leaves of apricot trees (Prúnus armeníaca) in the residential area on the street Kavkazskaya where S $(0,07$ $0,55 \%), \mathrm{P}(0,04-0,52 \%)$. 


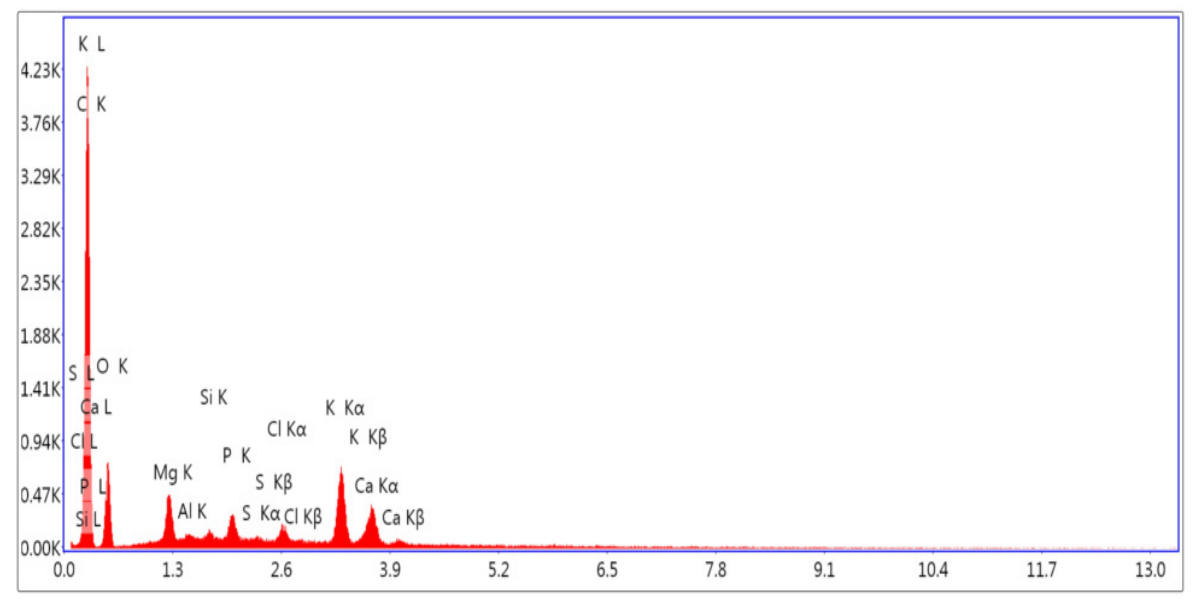

Lsec: 29.20 Cnts 0.000 keV Det: Apollo X-SDD Det Reso

Fig. 4. The chemical composition of dust particles from apricot leaves trees (Prúnus armeniaca) with $\mathrm{P}, \mathrm{S}, \mathrm{Fe}$ on the street Kavkazskaya.

The chemical composition of dust particles on the leaves of apricot trees (Prúnus armeniaca) was compared with the chemical composition of house dust in private houses of local residents, which was also collected in the residential area $f$ the Sredneakhtubinsky district of the Volgograd region in low-rise buildings. A photo of house dust from private households is shown in the figure. $5(\mathrm{~A}, \mathrm{~B})$.

A)

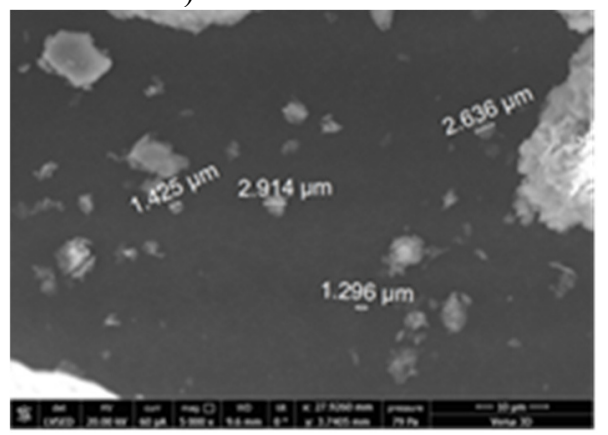

B)

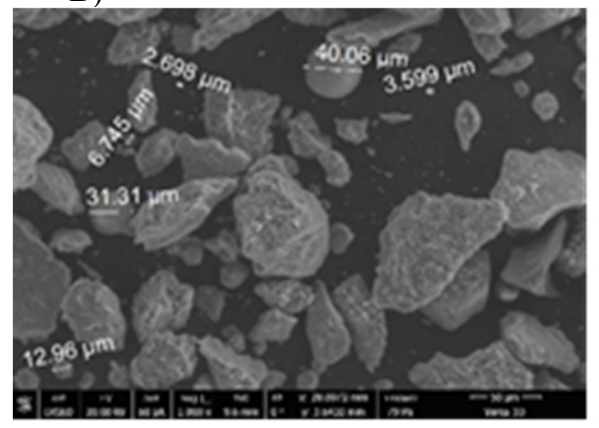

Fig. 5. Photo of house dust from private households in the residential area of the Sredneakhtubinsky district of the Volgograd region.

The results of a comparative analysis of the chemical composition of dust particles on the leaves of apricot trees (Prúnus armeníaca), the chemical composition of the leaves of apricot trees (Prúnus armeníaca) without dust and house dust in the residential area of the Sredneakhtubinsky district of the Volgograd region are shown in Table 1. 
Table 1. Comparative characteristics of the chemical composition of dust particles on the leaves of apricot trees (Prúnus armeníaca), leaves of apricot trees (Prúnus armeníaca) without dust and house dust in the residential area of the Sredneakhtubinsky district of the Volgograd region.

\begin{tabular}{|c|c|c|c|c|c|}
\hline No & $\begin{array}{c}\text { Chemical } \\
\text { element }\end{array}$ & $\begin{array}{c}\text { Mass of } \\
\text { chemical } \\
\text { element, \% } \\
\text { (House dust) }\end{array}$ & $\begin{array}{c}\text { Mass of } \\
\text { chemical } \\
\text { element, \% } \\
\text { (leaf dust) }\end{array}$ & $\begin{array}{c}\text { Mass of } \\
\text { chemical } \\
\text { element, \% } \\
\text { (leaves without } \\
\text { dust in a } \\
\text { residential } \\
\text { area) }\end{array}$ & $\begin{array}{c}\text { Mass of } \\
\text { chemical } \\
\text { element, \% } \\
\text { (leaves without } \\
\text { dust in } a \\
\text { relatively clean } \\
\text { area) }\end{array}$ \\
\hline 1. & $\mathrm{C}$ & 52.09 & 68.02 & 65.51 & 58.61 \\
\hline 2. & $\mathrm{O}$ & 56.48 & 44.44 & 30.4 & 34.38 \\
\hline 3. & $\mathrm{Mg}$ & 10.49 & 2.1 & 0.17 & 0.24 \\
\hline 4. & $\mathrm{Al}$ & 3.5 & 2.29 & 0.36 & 0.29 \\
\hline 5. & $\mathrm{Si}$ & 31.91 & 8.86 & 0.53 & 0.4 \\
\hline 6. & $\mathrm{Cl}$ & - & 1.64 & 0.15 & 0.59 \\
\hline 7. & $\mathrm{~K}$ & 2.04 & 5.47 & 2.06 & 4.86 \\
\hline 8. & $\mathrm{Ca}$ & 13.94 & 26.79 & 0.82 & 0.63 \\
\hline 9. & $\mathrm{Fe}$ & 4.9 & 0.61 & - & - \\
\hline 10. & $\mathrm{~F}$ & - & 3.51 & - & - \\
\hline 11. & $\mathrm{Mo}$ & - & 0.36 & - & - \\
\hline 12. & $\mathrm{P}$ & 0.82 & 0.52 & - & - \\
\hline 13. & $\mathrm{~S}$ & 0.58 & 0.55 & - & - \\
\hline 14. & $\mathrm{Ti}$ & 0.11 & - & - & \\
\hline
\end{tabular}

As can be seen from table 1, the chemical composition of the leaves of apricot trees (Prúnus armeníaca) (clean leaves without dust) in the relatively clean area and in the residential area is the same and is determined $\mathrm{C}, \mathrm{O}, \mathrm{Mg}, \mathrm{Al}, \mathrm{Si}, \mathrm{Cl}, \mathrm{K}, \mathrm{Ca}$ (Fig. 6,7).

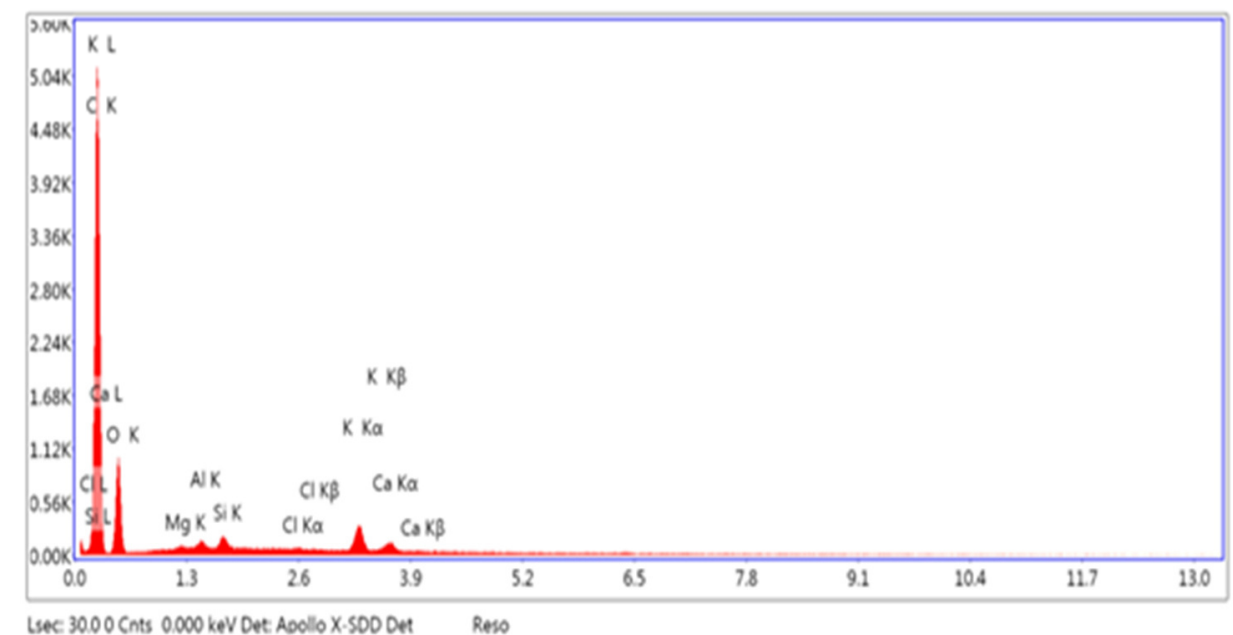

Fig. 6. The chemical composition of apricot leaves trees (Prúnus armeníaca) in a relatively clean area. 


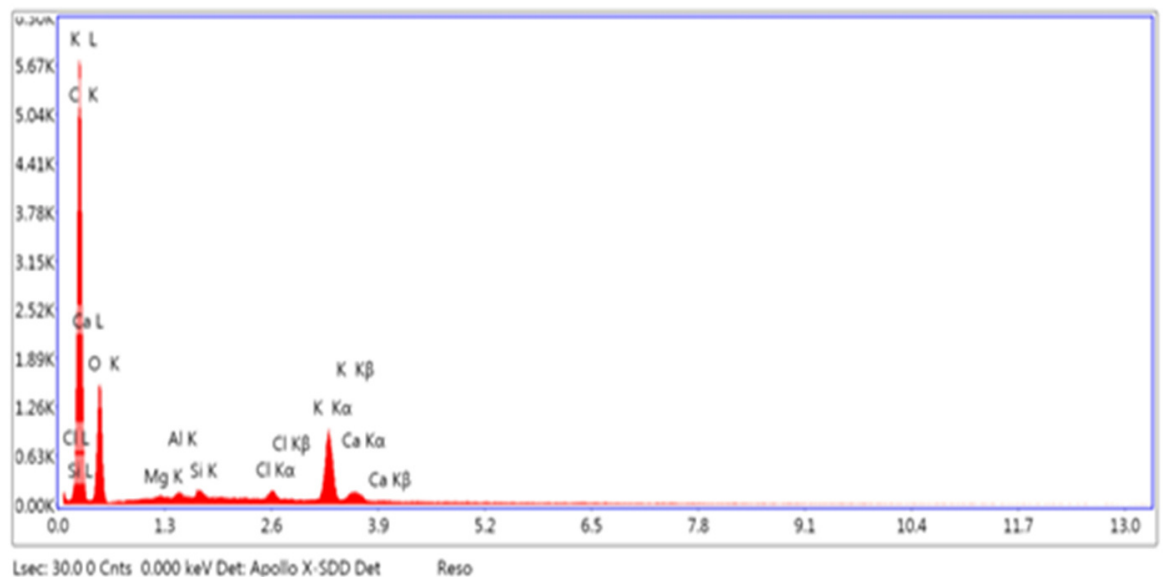

Fig. 7. The chemical composition of apricot leaves trees (Prúnus armeníaca) in the residential area.

In house dust were found practically all the same chemical elements, that were found in dust particles from leaf blades of apricot trees (Prúnus armeníaca). It:: $\mathrm{C}, \mathrm{O}, \mathrm{Mg}, \mathrm{Al}, \mathrm{Si}, \mathrm{Cl}$, $\mathrm{K}, \mathrm{Ca}$, P. Other chemical elements were found, such as Ti, Na, which were not detected in the dust on the leaf blades of apricot trees (Prúnus armeníaca). Titanium (Ti) is detected in small quantities $(<1 \%)$, Na (0,26-1,09\%). In apricot tree leaves (Prúnus armeníaca) and household dust silicon ( $\mathrm{Si}$ ) was detected. However, there is almost 30 times more silicon in house dust than on apricot tree leaves (Prúnus armeníaca). Meanwhile, in the house dust were not detected: Cl, F, Mo. An example of the chemical composition of house dust in one of the samples from private households on the street Omskaya (Fig. 8).

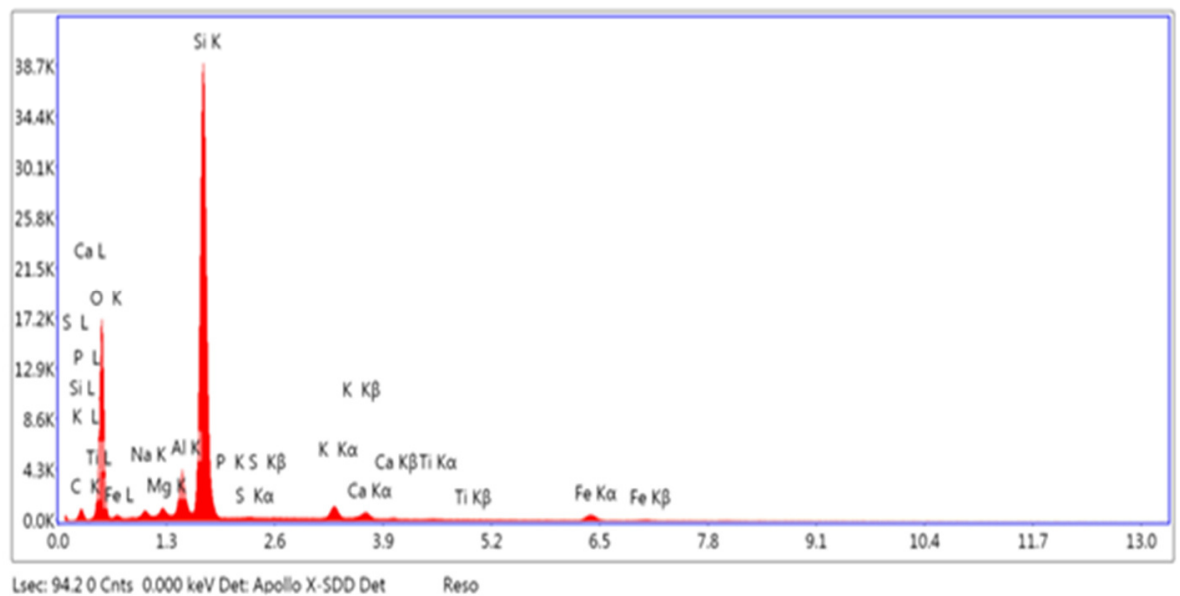

Fig. 8. The chemical composition of household dust in private households in the residential area (for example, Omskaya St.).

\section{Conclusion}

A study of the small-dispersed dust chemical composition on the leaves of apricot trees (Prúnus armeníaca) revealed such chemical elements as: F, P, S, Fe, Mo, which are not specific for leaf blades of a given plant species and are most likely environmental pollutants 
that enter the leaves from atmospheric air. This was discovered by studying the chemical composition of clean, washed leaves of apricot trees (Prúnus armeníaca) from a conditionally clean zone in SNT "Prospector" (the shore of the Bereslav reservoir) and from a residential zone of the Sredneakhtubinsky district of the Volgograd region. It can be concluded, that $\mathrm{C}, \mathrm{O}, \mathrm{Mg}, \mathrm{Al}, \mathrm{Si}, \mathrm{Cl}, \mathrm{K}, \mathrm{Ca}$ - re classical chemical elements that are present in certain quantities directly in the leaves of this plant species (Table 1). Environmental risks for local residents can create silicon and its compounds, which can get into households from atmospheric air when ventilating living quarters, as well as calcium compounds that were found on apricot tree leaves (Prúnus armeniaca) almost 20 times exceeding their values compared to the relatively clean zone (SNT "Prospector"). In the future, work is to be done to find out the sources of residential pollution by chemical elements and their compounds in the Sredneakhtubinsky district of the Volgograd region and to develop environmental measures [9] aimed at reducing pollutants emissions into the environment and improving the quality of life of the population.

\section{References}

1. N.V. Zaitseva, I.V. May, A.A. Max, S.Yu. Zagorodnov, Analysis of the dispersion and component composition of the dust to assessment of the exposure to the population in areas of influence of industrial emissions of stationary sources, Hygiene and sanitation, 5, 19-23 (2013).

2. C. S. Kapoor, B. R. Bamniya, K. Kapoor, Efficient control of air pollution through plants, a cost-effective alternative: studies on Dalbergia sissoo Roxb, environmental monitoring and assessment, 185 (9), $7565-7580$ (2013).

3. S. Norouzi, H. Khademi, A. Faz Cano [etc.], Using plane tree leaves for biomonitoring of dust borne heavy metals: A case study from Isfahan, Central Iran, Ecological Indicators, 57, 64-73 (2015).

4. S.S. Ram, S. Majumder, P. Chaudhuri, A Review on Air Pollution Monitoring and Management Using Plants with Special Reference to Foliar Dust Adsorption and Physiological Stress Responses, Critical Reviews In Environmental Science And Technology, 45 (23), 2489-2522 (2015).

5. K.M. Cardoso, A. De Paula, J.S. Dos Santos [etc.], Use of species of urban trees in environmental pollution biomonitoring, Ciencia Florestal, 27 (2), 535-547 (2017).

6. J. Franzaring, G. E. Mbaka, T. F. Ambebe [etc.], Foliar nutrient and metal levels of crops in the Mount Cameroon area-reference values for plant nutrition and environmental monitoring, Environmental Monitoring and Assessment, 189 (4) (2017).

7. A.Zh. Tashekova, A.S. Toropov, Application of leaves as biogeoindicators of urban environment state, Bulletin of the Tomsk Polytechnic University. Geo-Resource Engineering, 328 (5), 114-124 (2017).

8. P. Li, X. Sun, J. Chen [etc.], Absorption of the natural radioactive gas Rn-222 and its progeny (210) pb by Spanish moss Tillandsia usneoides and its response to radiation, Environmental And Experimental Botany, 158, 22-27 (2019).

9. I.Yu. Glinyanova, V.N. Azarov, A.N. Gorodnichaya, V.N. Fomichev, A.I. Melnichenko, Phytomonitoring and industrial phytodesign: new approach to ensure the environmental safety of the urban environment, Sociology of the city, 3, 83-93 (2018). 